\title{
Risk Analysis of Tender Documents on the Execution of Private Construction Work at Badung Regency, Bali Province, Indonesia
}

\author{
Ni Kadek Sri Ebtha Yuni ${ }^{1}$, I Nyoman Norken ${ }^{1}$, Dewa Ketut Sudarsana ${ }^{1} \&$ Ida Bagus Putu Adnyana ${ }^{1}$ \\ ${ }^{1}$ Faculty of Engineering, Udayana University, Badung, Bali, Indonesia \\ Correspondence: Ida Bagus Putu Adnyana, Faculty of Engineering, Udayana University, Badung, Bali, Indonesia. \\ Tel: 62-821-133-809-777. E-mail: bagusadnyana32@gmail.com
}

Received: January 23, 2017

doi:10.5539/jsd.v10n4p130
Accepted: May 9, 2017 Online Published: July 30, 2017

URL: https://doi.org/10.5539/jsd.v10n4p130

\begin{abstract}
Documents received during the tender, are in the form of drawings, specifications, bill of quantity (BQ), and the general terms of the contract. Tender activity will bring a variety of risks during the project implementation, and this research is done to identify and assessment of risks, mitigating risk and determining the ownership of the dominant risk. The research was conducted on a private building construction project at Badung Regency in Bali, by using a qualitative method and data collection was done through interview, brainstorming with experts and questionnaires. Among the 39 risk identified, 15 risks were obtained from the previous research, and the remaining 24 risks in this research.The results of this risk assessment were that 18 risks (46.2\%) categorized into unacceptable, that include: the addition items of work, the drawing does not match with plan, and the changes in the material specifications. Risk assessment fell into the undesirable category that 21 risks (53.8\%), including the mismatch information from planners, the arithmetic error, and materials used were not available on the market. Mitigation was done to dominant risk, among others by reassessing, submitting the contract change order, and asking questions. The biggest risk of ownership was the contractor, namely 39 risks with 18 unacceptable and 21 undesirable risks, this mean, problems associated with tender documents should receive the attention to contractors, planner consultants, owners and Quantity Surveyor (QS) consultants. Contractors as the recipient of the biggest risk were expected to increase the competence of those involved in the tender process.
\end{abstract}

Keywords: tender documents, risk, identification, assessment, mitigation, and risk ownership

\section{Introduction}

Contractor seeks to acquire projects in the construction sector, generally through the tender process. This process is very important for entrepreneurs in the field of construction services, because the continuity of its business depends on the success or failure of this process (Ervianto, 2004). The project owner will conduct the bidding process to obtain the appropriate contractor, based on the desired requirements. These requirements are set forth in the tender documents, issued by the tender committee in the form of tender book. This book contains the work plan and the terms, the general provisions of the tender, definitions, requirements of the tender participants, scope of work, the timing of the work, the preparation of the bid, and the format of statement letter (Suherman, 2010). Tender documents such as tender drawings, technical specifications and work plans and requirements and the addendum document.

At each stage of the project there is always a risk. Results of research on Vale Project Risk Management in PT. Multipanel Intermitra Mandiri showed that the impact of dangerous project risks derived from changes in the specifications of customer orders and delays in the completion of activities (Setiawan, 2014). Research on the project risks by the lump sum contract and the unit price contract found that the identified risks sourced from the planning stage as many as 9 risks, such as those relating to the tender document i.e. a redesign of the planning consultant, in which the clarity and the completeness of the tender documents should be double-checked, experience in reading the plan drawings, and the experience in making budget plan bidding (Suwandi, 2010). Other studies on the risk of the project completion time, it was found that based on the frequency of occurrence, risks of the most common are the additional works, the change of the construction works and changes in the technical specifications (Arie and Artama. 2008).

The problems that occurred in the construction of hotels in Tanjung Benoa related to tender documents were the difference between the tender drawings and the real conditions, the lack of volume of works, and the difference 
between the tender drawings and the drawings for construction. Other problems also occurred in the construction of hotels in the Kuta area, for examples, the work items that were not listed in the bidding documents, the document drawings were not received at the time of the tender, the loss of the receipt of tender documents. These risks may result in the addition or reduction of costs, and affect the project implementation time. Based on the above problems, it is necessary to carry out an analysis on the risks at the time of project implementation as a result of the tender documents on the construction project, especially in the construction projects in Badung, so that the monitoring and controlling can be done to reduce the adverse impact on the company.

\section{Literature Review}

\subsection{Definition of Tender}

In the implementation of the procurement of goods or services, there are several parties involved and interconnected (Suputra, 2005), among others:

1) The User of the Services is a person or legal entity or government that has work projects, that requires the procurement of goods and services, as well as providing all necessary expenses.

2) A Planner is a person or legal entity whose work and business to make the planning technically upon the user's request.

3) A Contractor is a person or legal entity whose work and business to acquire goods or carry out the work based on the customer's demand, in accordance with the agreed contract.

It is further specified that the activities of the procurement of goods and services, usually the user will make up the tender committee. The committee is carrying out the entire tender process, ranging from preparing procurement documents, resolving and selecting prospective contractors / consultants, requesting a quote and evaluating them, proposing the prospective contractors / consultants, as well as providing contract documents.

\subsection{Tender Documents}

Tender documents are documents that have been made by the tender committee with the consent of the user. Making the tender documents are one of the stages in the procurement of the tender. Tender documents of the committee are in the form of technical specifications, tender drawings, as well as appendices (Suherman, 2010).

1) Tender drawing is a drawing used as a basis for the calculation of the Budget Plan bid by the contractor. Tender drawing is made more precise and detailed than a plan drawing. In a tender drawing, all information must be clear, detailed and easy to read .

2) Work Plan and Conditions is a description of duties and responsibilities, administrative requirements and instructions for the service provider. RKS contents are as follows:

a. General terms, describing the the works to be done, the institutions involved, the name of the owner of the project.

b. Special conditions, which describe the collection date of the bids, the payment method, the type of contract used, the use of bid security and performance security, and the period of construction.

c. Technical requirements, which contain the specification of the material used, the type and items of work to be done, the working methods used and the brand used.

3) Appendices constitute additional statement, which contains a bill of quantity (BQ), a list of the analysis of unit prices of materials and wages, letters of bidding guarantee, performance bonds, price quotes (SPH), and the form of a letter of offer/bid.

The tender documents include the addendum document. Document addendum is an addition or reduction of the tender documents. Each of the addendum must be issued in writing sent to all bidders. Documents that can be incorporated into the addendum are the official report ofaanwijzing(instructions), the official report of clarification, the answers to questions from bidders, and all document changes. The documents received in the tender will become a reference in preparing contract documents, by the addendum of written agreement, the date of commencement of work, the expiration date of the work.

\subsection{Definition of Risk}

Risk is the possibility of financial loss, damage or physical injury, the delay due to the uncertainty. Risks that occur in the construction project will affect the project objectives, costs, time, and quality of the project. Implementation of the project is always referring to the estimate made at the time of planning, to reduce the risk of project failure (Norken et al. 2015). The construction project is getting a high level of complexity, involving 
many disciplines, so that the role of risk management must be more intensive.

Failure to maintain the estimated costs that have been planned, failure to complete the project on time, and the failure to achieve a predetermined quality are the most serious risks of the project. Implementation of risk management aims to prevent losses, and other problems that are not expected. Risks can occur because of the uncertainty between planning and execution. This uncertainty is due to the limitation of information and knowledge.

\subsection{Risk Management}

Risk management is related to the methods used by companies or institutions to prevent and to reduce the risks that may be encountered. The risk management process has been undertaken to identify, to analyze and to respond to the risks of a project, to reduce its impact, which is done through a variety of procedures, by making an organization to manage and to monitor it. Risk management is an activity to determine the risk, to assess the risk, to determine action in the face of these risks. Strategies that can be taken are by avoiding risks, and reducing the risk of negative effects. Risk management focuses its attention on the systematic way in terms of identifying, analyzing and responding to the risks. The uncertainty of risk on the project will affect the project goals and objectives. Uncertainty due to human activities / technologies could be reduced by exploring more information and applying a better model. Risk management should be done throughout the project cycle from the beginning to the end of the project (Husen, 2011).

\subsection{Risk Identification}

The process to find out the risks that occur in an activity is called risk identification. Risk identification can be done based on the causes, the incidence and the impact. In risk management, risk identification process is the initial stage in determining the risks that may occur.

At the stage of risk identification, many difficulties will be experienced, due to inability to identify the overall risk considering the uncertainty of what to expect. To make it easier to identify the risks, it first must be identified the source of risk, incidence, and the effect of those risks. The means used to make it easier to identify the risks, namely by making a list of risks, conducting interviews with personnel who are experts in the areas being identified, carrying out discussion on a particular topic (brainstorming) and keeping records of the event (Suwandi, 2010).

\subsection{Qualitative Risk Management and Analysis}

There are two methods to analyze risk, i.e. the method of qualitative analysis and quantitative analysis. Risk analysis begins with qualitative analysis, and if necessary, followed by quantitative analysis. Qualitative analysis focused on risk identification, risk assessment by descriptive analysis, while quantitative analysis performs the analysis of probabilities, the sensitivity analysis, scenario analysis, simulation and correlation analysis. Analysis and qualitative risk management has the objective to identify and to assess risks. Qualitative risk analysis will be able to determine the dominant risk (major risk) based on the multiplier between the frequency and consequences of the risks and the impacts that should be assessed or analyzed.

\subsection{Assessment and Acceptance of Risks}

The risk assessment is the assessment of the effects of risks that have been identified, which can be included as the major risk categoryi.e. a risk with the greatest effect thatneeds management. While the minor risk does not require special handling. The magnitude of the risk effects can be determined by multiplying the risk modeby frequency mode with the risk mode by the consequences (Godfrey et al. 1996). The risk assessment that is based on multiplying the frequency mode with the mode of the consequences can be classified as: Unacceptable (a risk that can not be tolerated), Undesirable (a risk that requires treatment), Acceptable (an acceptable risk) and negligible (the risk of which can be neglected), as shown in Table 1 and Table 2.

\subsection{Risk Mitigation}

Risk mitigation is conducted with the aim of determining the measures to reduce the effects of risk that has been identified. Identification of mitigation measures is done by means of interviews with experts in the fieldand brainstorming, in order to obtain treatment measures against the major risks.

\subsection{Risk Allocation}

Risks that have been identified and classified were then allocated to the various contracting parties. The risk allocation is done on the parties responsible for the risks, those who are able to handle the risks, and the responsible parties in the event of uncontrollable risks. The allocation of risk is based on the duties and responsibilities of the parties involved in the project. The risk allocation is the determination and the devolution 
of responsibility for the risks [6].

Table 1. Scale of risk acceptability

\begin{tabular}{cc}
\hline Acceptability of Risk & Risk Acceptability \\
\hline Unacceptable & $\mathrm{X}>12$ \\
Undesirable & $5 \leq \mathrm{X} \leq 12$ \\
Acceptable & $2<\mathrm{X}<5$ \\
Negligible & $\mathrm{X} \leq 2$ \\
\hline \multicolumn{2}{c}{ Source: (Godfrey et al. 1996$).$}
\end{tabular}

Table 2. Assessment and risk acceptability

\begin{tabular}{cccccc}
\hline $\begin{array}{c}\text { Consecquence } \\
(\text { Scale })\end{array}$ & Catastrophic & Critical & Serious & Marginal & Negligible \\
Likelihood & $(5)$ & $(4)$ & $(3)$ & $(2)$ & $(1)$ \\
$($ Scale $)$ & & & & & \\
\hline Frequent & Unacceptable & Unacceptable & Unacceptable & Undesirable & Undesirable \\
$(5)$ & $(25)$ & $(20)$ & $(15)$ & $(10)$ & $(5)$ \\
Probable & Unacceptable & Unacceptable & Undesirable & Undesirable & Acceptable \\
$(4)$ & $(20)$ & $(16)$ & $(12)$ & $(8)$ & $(4)$ \\
Occasional & Unacceptale & Undesirable & Undesirable & Undesirable & Acceptable \\
$(3)$ & $(15)$ & $(12)$ & $(9)$ & $(6)$ & $(3)$ \\
Remote & Undesirable & Undesirable & Undesirable & Acceptable & Negligible \\
$(2)$ & $(10)$ & $(8)$ & $(6)$ & $(4)$ & $(2)$ \\
Improbable & Undesirable & Acceptable & Acceptable & Negligible & Negligible \\
$(1)$ & $(5)$ & $(4)$ & $(3)$ & $(2)$ & $(1)$ \\
\hline
\end{tabular}

Source: (Godfrey et al. 1996).

\section{Research Methods}

The scopes of the research are:

1) Identifying the risks so as to determine the acceptability of risk associated with the tender documents on the implementation of private construction projects in the Badung Regency.

2) Conducting a risk assessment so as to determine the acceptability of risk associated with the tender documents on the implementation of private construction projects in the Badung Regency.

3) Determine the dominant or major risks associated with the tender documents on the implementation of private construction projects in the Badung Regency.

4) Mitigating the risks that may occur and allocating risk ownership against the major risk associated with the tender documents on the implementation of private construction projects in the Badung Regency.

Methods of data collection were conducted by surveys and interviews with respondents who are experts in their field. The purpose of the survey and the interview was to get the opinions of the respondents regarding the risks that becoming problems related to the tender documents. The research used qualitative analysis of identifying the risks based on surveys and interviews on the experienced people related to the problemsbeing analyzed, followed by conducting a risk assessment, defining mitigation and risk ownership.

The data used were secondary data obtained by the review of the journal, literature, reports and other studies related to project risk management. Primary data were taken directly from the researh object, ie, respondents from the competent parties concerning the problems of implementation of work related to the tender documents, 
obtained by interview, brainstorming and discussions.

The collection of the respondents in the research were conducted by using purposive sampling method, or a deliberate selection of respondents. Respondents were stakeholders who work in contractors, construction management consultants, and the Quantity Surveyors with a total of 25 respondents.

\section{Results and Discussion}

\subsection{Identifying Risks}

The results of the initial risk identification were 42 risks. It was then followed by a preliminary survey by distributing questionnaires to 10 respondents. Because the validity and reliability of test results of the initial survey was valid and reliable, then it proceeded with evaluating the risk identification. Identification of risks after being evaluated has become 39 risks, because there was a statement that has the same meaning in the initial identification. The source of risk stems from the planning (23 risks), human risks (14), economic risks (1), environmental risks (1). Of the 39 risk identification, 13 risks were found from the previous research, and 26 risks were obtained from this research. Source of risks that comes from the planning was 23 risks, 14 human risks, 1 environmental risk and 1 economic risk.

\subsection{Validity and Reliability Test Results}

Validity test aims to determine whether the statements of a research can measure what items want to be measured. The validity test used the software program of Statistical Package for Social Science (SPSS) for Windows version 17.0. Based on the test validity of $\mathrm{r}$ table for 10 respondents with $\mathrm{df}$ (degree of freedom) $=(\mathrm{N}-2)$, it was obtained acorrelation coefficient of 0.5494 . The validity test of the instrument indicates that the Product Moment correlation coefficient value of each instrument was greater than 0.5494 , this indicates a valid research instrument. Reliability was measured by alpha coefficients. The results of the analysis by SPSS found that all alpha coefficients (Cronbach's Alpha) $>0.60$, this suggests that the instruments used were reliable.

\subsection{Risk Assessment}

From the analysis of multiplication of the frequency mode and consequence mode, it was obtained two categories, namely unacceptable category of risk totalling 18 risks, undesirable risks were 21 risks. The category of unacceptable risks was derived from the planning risk of 15 risks, 2 of human risks, and 1 of economic risk . Undesirable Risk category came from 8 risks of the planning risks, 12 of human risks, and 1 of environmental risk. Of the 39 identified risks tender documents, all of which require handling because the result of the risk assessment was unacceptable and undesirable which can be seen in Table 3 and Table 4.

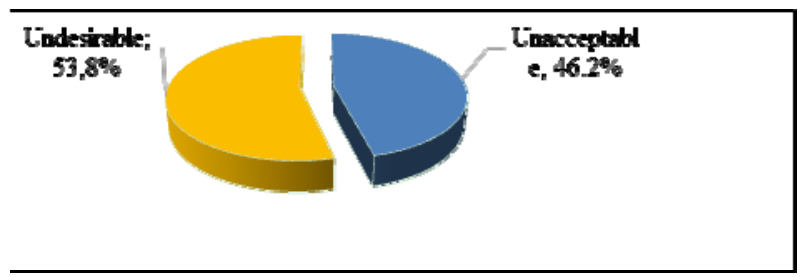

Figure 1. Major Risks

Source: the Results of Research, 2016

The major risks are risks that categorized as unacceptable and undesirable. The existence of major risks would have great impact on the implementation of private construction work in Badung, so it should get special attention from the parties responsible for the occurrence of such risks. 
Table 3. Unacceptable risk acceptability

\begin{tabular}{|c|c|c|c|}
\hline $\begin{array}{l}\text { Risk } \\
\text { No. }\end{array}$ & Risks & $\begin{array}{l}\text { Risk } \\
\text { value }\end{array}$ & $\begin{array}{l}\text { Risk } \\
\text { Acceptability }\end{array}$ \\
\hline & Planning Risk & & \\
\hline 1 & $\begin{array}{l}\text { Data / documents from planners (drawings, specifications, BQ and other data) are } \\
\text { incomplete. }\end{array}$ & 25 & Unacceptable \\
\hline 2 & Plan drawings / tender drawings did not match with the reality & 20 & Unacceptable \\
\hline 3 & Mismatches between the project work volumes and the field conditions. & 20 & Unacceptable \\
\hline 5 & The addition of items of work. & 20 & Unacceptable \\
\hline 6 & Changes in material specification used. & 20 & Unacceptable \\
\hline 7 & Given documents are unclear. & 16 & Unacceptable \\
\hline 8 & Lack of experience in reading the plan drawings at the time of the initial planning. & 20 & Unacceptable \\
\hline 10 & Changes in the work execution time. & 25 & Unacceptable \\
\hline 11 & Mistakes in planning the execution time. & 20 & Unacceptable \\
\hline 13 & Inaccuracy of estimated costs. & 20 & Unacceptable \\
\hline 14 & The lack of detailed drawings in the plan drawings. & 16 & Unacceptable \\
\hline 15 & $\begin{array}{l}\text { Differences of layout/ plan drawing between drawing of structure, architecture } \\
\text { and MEP. }\end{array}$ & 20 & Unacceptable \\
\hline 16 & Differences in the specifications between the drawings and the offers/bids. & 20 & Unacceptable \\
\hline 21 & $\begin{array}{l}\text { Design drawing at the time of the tender has not been shown, but at the time of } \\
\text { construction the design is shown. }\end{array}$ & 20 & Unacceptable \\
\hline 22 & $\begin{array}{l}\text { Work items which are not listed in the offer, but shown in the drawings. } \\
\text { Human Risks }\end{array}$ & 20 & Unacceptable \\
\hline 29 & $\begin{array}{l}\text { There were arithmetic errors (the errors of multiplication and addition) in the } \\
\text { making of the bids. }\end{array}$ & 15 & Unacceptable \\
\hline 36 & $\begin{array}{l}\text { In a letter of price quote is not listed the notes concerning work items clearly and } \\
\text { the specifications offered. }\end{array}$ & 16 & Unacceptable \\
\hline 39 & $\begin{array}{l}\text { Economic Risk } \\
\text { The significant price increases affecting the prices of materials and the labor } \\
\text { costs. }\end{array}$ & 16 & Unacceptable \\
\hline
\end{tabular}

Source: the results of research, 2016 
Table 4. Undesirable risk acceptability

\begin{tabular}{|c|c|c|c|}
\hline RiskNo. & Risks & Risk value & Risk Acceptability \\
\hline & Planning Risk & & \\
\hline 4 & $\begin{array}{l}\text { Mismatches of information provided by the owner of the real } \\
\text { conditions in the project site. }\end{array}$ & 12 & Undesirable \\
\hline 9 & Selection of subcontractors that are less good. & 12 & Undesirable \\
\hline 12 & Planning of work methods that are less precise. & 12 & Undesirable \\
\hline 17 & $\begin{array}{l}\text { Differences of specifications listed in the drawing from the } \\
\text { one in the book of specifications. }\end{array}$ & 12 & Undesirable \\
\hline 18 & $\begin{array}{l}\text { Many work items are provisional sum / volume and material } \\
\text { recalculated in accordance with the conditions in the project } \\
\text { site. }\end{array}$ & 9 & Undesirable \\
\hline 19 & $\begin{array}{l}\text { Material changes that were originally supplied by the owner } \\
\text { into by contractor. }\end{array}$ & 12 & Undesirable \\
\hline 20 & $\begin{array}{l}\text { Material changes that were originally supplied by contractor } \\
\text { into by the owner. }\end{array}$ & 8 & Undesirable \\
\hline 23 & $\begin{array}{l}\text { The material used is not available in the market. } \\
\text { Human Risks }\end{array}$ & 9 & Undesirable \\
\hline 24 & $\begin{array}{l}\text { Lack of understanding of the location / situation of the project } \\
\text { to be built. }\end{array}$ & 8 & Undesirable \\
\hline 25 & $\begin{array}{l}\text { Did not make the meeting minutes of the job descriptions } \\
\text { (aanwijzing). }\end{array}$ & 6 & Undesirable \\
\hline 26 & The loss of minutes of the meeting. & 6 & Undesirable \\
\hline 27 & $\begin{array}{l}\text { The loss of the receipt of tender documents provided by the } \\
\text { tender committee. }\end{array}$ & 6 & Undesirable \\
\hline 28 & Does not specify the validity periods in the price quotes. & 8 & Undesirable \\
\hline 30 & $\begin{array}{l}\text { The cost estimate is not compared to the actual field } \\
\text { conditions. }\end{array}$ & 12 & Undesirable \\
\hline 31 & $\begin{array}{l}\text { There are specifications mentioned as "equivalent" is not } \\
\text { classified so that the price offered is different. }\end{array}$ & 9 & Undesirable \\
\hline 32 & $\begin{array}{l}\text { The obscurity scope of work offered by the subcontractor / } \\
\text { supplier. }\end{array}$ & 9 & Undesirable \\
\hline 33 & Request a quote to the unknown subcontractor / supplier. & 12 & Undesirable \\
\hline 34 & $\begin{array}{l}\text { Not studying the contents of the minutes of the } \\
\text { aanwijzingmeeting and the clarification. }\end{array}$ & 8 & Undesirable \\
\hline 35 & $\begin{array}{l}\text { Not read in detail the contents of the bids of the } \\
\text { subcontractors / suppliers, so that there are notes not taken } \\
\text { into account at the time of bidding. }\end{array}$ & 12 & Undesirable \\
\hline 37 & $\begin{array}{l}\text { Not studying the general terms of contract } \\
\text { Environmental Risks }\end{array}$ & 12 & Undesirable \\
\hline 38 & $\begin{array}{l}\text { Not paying attention to the environmental regulations around } \\
\text { the project to be built }\end{array}$ & 12 & Undesirable \\
\hline
\end{tabular}

Source: the results of research, 2016 


\subsection{Risk Mitigation}

Result of compiling the unacceptable risk mitigation is presented in Table 5 and the undesirable risk mitigation in Table 6.

Table 5. Unacceptable risk mitigation

\begin{tabular}{|c|c|c|c|c|}
\hline $\begin{array}{l}\text { Risk } \\
\text { No. }\end{array}$ & Risk Identifications & $\begin{array}{l}\text { Risk } \\
\text { value }\end{array}$ & $\begin{array}{l}\text { Risk } \\
\text { Acceptability }\end{array}$ & Risk Mitigation \\
\hline & \multicolumn{4}{|l|}{ Planning Risk } \\
\hline 1 & $\begin{array}{l}\text { Data / documents from planners (drawings, } \\
\text { specifications, BQ and other data) are } \\
\text { incomplete. }\end{array}$ & 25 & Unacceptable & $\begin{array}{l}\text { a. Reading / checking all documents } \\
\text { issued. } \\
\text { b. To recalculate or submit } \\
\text { ContractChange Order to adjust to } \\
\text { conditions in the project site. }\end{array}$ \\
\hline 2 & $\begin{array}{l}\text { Plan drawings / tender drawings did not match } \\
\text { with the reality }\end{array}$ & 20 & Unacceptable & $\begin{array}{l}\text { a. Planning consultant should conduct a } \\
\text { study on the condition of the field at } \\
\text { the time ofplanning. } \\
\text { b. Conduct a review of the design to suit } \\
\text { the conditions in the project site. }\end{array}$ \\
\hline 3 & $\begin{array}{l}\text { Mismatches between the project work volumes } \\
\text { and the field conditions. }\end{array}$ & 20 & Unacceptable & $\begin{array}{l}\text { a. Take a field trip when estimating the } \\
\text { plan drawing with the purpose of } \\
\text { comparing with the field conditions }\end{array}$ \\
\hline 5 & The addition of items of work. & 20 & Unacceptable & $\begin{array}{l}\text { a. Discuss and propose appropriate } \\
\text { changes in the real field conditions. } \\
\text { b.Discuss and propose changes in the } \\
\text { volume of work with ContractChange } \\
\text { Order }\end{array}$ \\
\hline 6 & Changes in material specification used. & 20 & Unacceptable & $\begin{array}{l}\text { a. Conducting joint discussion related to } \\
\text { specificationchanges toadjust with the } \\
\text { budget. } \\
\text { b.Discuss and propose changes in the } \\
\text { volume of work with ContractChange } \\
\text { Order }\end{array}$ \\
\hline 7 & Given documents are unclear. & 16 & Unacceptable & $\begin{array}{l}\text { a.Asking questions in the aanwijzing } \\
\text { meeting (job description), and its } \\
\text { clarification. }\end{array}$ \\
\hline 8 & $\begin{array}{l}\text { Lack of experience in reading the plan drawings } \\
\text { at the time of the initial planning. }\end{array}$ & 20 & Unacceptable & $\begin{array}{l}\text { a. Assigning experienced people in } \\
\text { planning cost estimation. }\end{array}$ \\
\hline 10 & Changes in the work execution time. & 25 & Unacceptable & $\begin{array}{l}\text { a. Make a realistic execution schedule } \\
\text { b.Conducting rescheduling }\end{array}$ \\
\hline 11 & Mistakes in planning the execution time. & 20 & Unacceptable & $\begin{array}{l}\text { a. Learn about the project items that will } \\
\text { be built and predict everyobstacles that } \\
\text { may occur }\end{array}$ \\
\hline 13 & Inaccuracy of estimated costs. & 20 & Unacceptable & a. Studying the drawings by comparing \\
\hline
\end{tabular}


14

The lack of detailed drawings in the plan drawings.

15

Differences of layout / plan drawing between drawing of structure, architecture and MEP.

16

Differences in the specifications between the drawings and the offers/bids.

Design drawing at the time of the tender has not

21 been shown, but at the time of construction the design is shown.

Work items which are not listed in the offer, but shown in the drawings.
Unacceptable

Unacceptable
Unacceptable thespecifications and the real conditions in the project site

b.Calculating the volume of work accurately

a.Asking questions at the meeting of aanwijzing (job description).

b.Request completeness of detailed drawings

a.Learn all the tender drawings given and comparing them with the stuctural, architectural, MEP, and interior drawings.

b. Conducting a design review

a.Making notes about the specifications offered at the time of bid submission

b. Making clarification at the meeting for clarification

a. Make a firm agreement on the scope of work of the contractor and the owner

a.Learn the drawings and make the work items in detail.

b. Efficiency of materials and wages by doing value engineering.

\begin{tabular}{|c|c|c|c|c|}
\hline & \multicolumn{4}{|l|}{ Human Risks } \\
\hline 29 & $\begin{array}{l}\text { There were arithmetic errors (the errors of } \\
\text { multiplication and addition) in the making of } \\
\text { the bids. }\end{array}$ & 15 & Unacceptable & $\begin{array}{l}\text { a.Double check of summation } \\
\text { andmultiplication }\end{array}$ \\
\hline 36 & $\begin{array}{l}\text { In a letter of price quote (SPH) is not listed the } \\
\text { notes concerning work items clearly and the } \\
\text { specifications offered }\end{array}$ & 16 & Unacceptable & $\begin{array}{l}\text { a. Make a record sheet related to the } \\
\text { scope of work and specifications } \\
\text { offered. } \\
\text { b.Making notes in the bids or price } \\
\text { quotes }\end{array}$ \\
\hline & \multicolumn{4}{|l|}{ Economic Risk } \\
\hline 39 & $\begin{array}{l}\text { The significant price increases affecting the } \\
\text { prices of materials and the labor costs. }\end{array}$ & 16 & Unacceptable & $\begin{array}{l}\text { a.Make arrangements with } \\
\text { subcontractors / suppliers related to } \\
\text { the period of construction and price. } \\
\text { b.Make negotiation }\end{array}$ \\
\hline
\end{tabular}

Source: the results of research, 2016 
Table 6. Undesirable risk mitigation

\begin{tabular}{|c|c|c|c|c|}
\hline Risk & Risk Identifications & Risk & Risk & Risk Mitigation \\
\hline No. & & value & Acceptability & \\
\hline
\end{tabular}

Planning Risk

Mismatches of information provided by the owner of the real conditions in the project site.

9 Selection of subcontractors that are less good.

12 Planning of work methods that are less precise.

17 Differences of specifications listed in the drawing from the one in the book of specifications.

18 Many work items are provisional sum / volume and material recalculated in accordance with the conditions in the project site.

19 Material changes that were originally supplied by the owner into by contractor.

20 Material changes that were originally supplied by contractor into by the owner.

23 The material used is not available in the market.

\section{Human Risks}

24 Lack of understanding of the location / situation of the project to be built.

25 Did not make the meeting minutes of the job descriptions (aanwijzing).

26 The loss of minutes of the meeting.

27 The loss of the receipt of tender documents provided by the tender committee.
12 Undesirable

a. Conduct a review of the design to suit the real conditions in the project site.

b. Discuss and propose changes to adjust with the real conditions in the project site.

$12 \quad$ Undesirable

a.Making comparisons with several subcontractors, both on the price quotes and technical as well as organizational structure.

12 Undesirable

a. Knowing the location and situation of the project.

b. Making changes to work methods to suit the project site conditions

Undesirable

a. Make notes about the specifications offered at the time of bid submission

Undesirable a. Conduct a review of design / completeness of the design.

b. Recalculating the volume, and submit the bid to the project owner

12 Undesirable

a. Make a firm agreement on the scope of work of the contractor and the owner

$8 \quad$ Undesirable

a. Make a firm agreement on the scope of work of the contractor and the owner.

b. Removing the work items from the project work contract.

$9 \quad$ Undesirable

a. Checking drawings and specifications used.

b. Making changes to the specifications, adjusted to the material available in the market.

$8 \quad$ Undesirable

a. visiting the project site and search for information about the project's surroundings

$6 \quad$ Undesirable

a. Recording the conversation with a recorder.

b. Photographing everything that is described in written form or material samples

$6 \quad$ Undesirable

a. Create / save it in a document file.

b. Attaching it in the book of contract.

Undesirable

a. Create / save it in a document file.

b. Saving it in an e-mail if sent via e-mail 
28 Does not specify the validity periods in the price quotes $(\mathrm{SPH})$.

30 The cost estimate is not compared to the actual field conditions.

31 There are specifications mentioned as "equivalent" is not classified so that the price offered is different.

32 The obscurity scope of work offered by the subcontractor / supplier.

Request a quote to the unknown subcontractor / supplier.

34 Not studying the contents of the minutes of the aanwijzing meeting and the clarification.

35 Not read in detail the contents of the bids of the subcontractors / suppliers, so that there are notes not taken into account at the time of bidding.

37 Not studying the general terms of contract

\section{Environmental Risks}

38 Not paying attention to the environmental regulations around the project to be built

\author{
Undesirable \\ a. Include a note regarding the validity period \\ of offers in the bid/price quotes \\ a. visiting the project site. \\ b. Comparing the drawings, specification with \\ the environment of the project \\ a. Asking questions in the aanwijzing meeting \\ (job description). \\ b.Making clarification at the clarification \\ meeting \\ Undesirable a.Clarify the subcontractors / suppliers that \\ submit the bids.
}

12 Undesirable

$9 \quad$ Undesirable

12 Undesirable

a.Looking for experienced subcontractors / suppliers that have references of the projects undertaken.

$8 \quad$ Undesirable

a. Attending the job description meeting and its clarifications.

b. Reading / re-examine the contents of the meeting minutes

12 Undesirable

a. Calling the sub-contractor / supplier to be able to provides explanations for the offers given.

b. Read and clarify the content of bids submitted.

12 Undesirable a. Attending the job description meeting.

b.Reexamine the terms of the contract that will be executed.

$12 \quad$ Undesirable a. visiting the project site and search for information about the project's surroundings

Source: the results of research, 2016

\subsection{Owners of Risks}

Contractors as the owners of the biggest risks of 39 risks (48.15\%) consisting of 18 unacceptable risks and 21 undesirable risks. Projects' owners as the recipients of risks as many as 15 owners (18.52\%), which consists of 8 unacceptable risks and 7 undesirable risks. Consultants of QualitySurveyor as the recipients of risks by 14 (17.28\%), which consists of 8 unacceptable risks and 6 undesirable risks. Planning consultants as the recipient of risks as many as $12(14.81 \%)$ consisting of 8 unacceptable risks and 4 undesirable risks. Government has 1 unacceptable risk $(1.23 \%)$ because the government is involved in determining the economic policies.

\section{Conclusion}

Risks of tender documents were identified as many as 39 risks, which derived from the planning as many as 23 risks, 14 human risks, 1 environmental risk and 1 economic risk. Of the 39 identified risks, 13 risks were obtained from previous research, and 26 identified risks were found in this research.

The results of the risk assessment of tender documents were 18 unacceptable risks and 21 undesirable risks. The risks categorizedas unacceptable risks were derived from the planning of 15 risks, 2 human risks, and 1 
economic risk. The risks categorized as undesirable risks i.e. 8 planning risks, 12 humanrisks and 1 environmental risk.

Risk mitigation by the unacceptable and undesirable categories can be anticipated by: a) Conducting a study of the real condition of the field, b) Conducting design reviews, c) re-calculation or submitting contract change order, d) Conducting joint consideration due to any differences, e) Addressing queries, f) Makingrecords, g) Making working agreement.

The contractors borne the biggest risks at 39 risks (48.15\%) the project owners had 15 risks $(18.52 \%)$, the QS consultants had 14 risks $(17.28 \%)$, the planning consultants had 12 risks $(14.81 \%)$, and the government had 1 risk (1.23\%).

\section{Acknowledgements}

This paper is part of the Civil Engineering master's thesis of Udayana University. The author would like to express hergratitude and appreciation to the Chairman of the Master of Civil Engineering of UdayanaUniversity and his staff as well as to all those who have provided support for the publication of this paper.

\section{References}

Arie, J. H., \& Artama, I. P. W. (2008). Analisa Resiko terhadap Waktu Penyelesaian Proyek pada Pembangunan Perumahan di Surabayar [Online] Tersedia di: http://mmt.its.ac.id/download/SEMNAS/SEMNAS\%20VIII/MP/1.\%20Prosiding\%20Julius\%20Arie-Ok-pri nt.pdf. [Diakses pada : 1 Desember 2015].

Astiti, N. P. M. (2014). Analisis Risiko Pelaksanaan Pembangunan Jalan Tol Benoa-Bandara-Nusa Dua. Denpasar: Universitas Udayana.

Bhakti, S., Wiguna, P. A., \& Susanto, A. (2013). Penentuan Risiko Jenis Kontrak pada Pembangunan Gedung di Lingkungan Total E\&P Indonesia. [Online] Tersedia di http://mmt.its.ac.id/download/SEMNAS/SEMNAS\%20XVII/MP/2.\%20\%20Semidang\%20Bhakti.pdf.

[Diakses pada : 1 Desember 2015].

Brahmatariguna, I. A. (2015). Hubungan Kompetensi Project Manager Terhadap Keberhasilan Proyek Konstruksi Gedung. Denpasar: Universitas Udayana.

Ervianto, W. I. (2004). Teori Aplikasi Manajemen Proyek konstruksi. Cetakan Kedua. Yogyakarta: Andi Offset.

Flanagan, R., \& Norman, G. (1993). Risk Management and Contruction. Cambridge : University Press.

Godfrey, Patrik S., Hacrow, Sir William \& Partner Ltd. (1996). Control of Risk A Guide to the Systematic Management of Risk from Construction. Westminster Londen: CIRIA.

Husen, A. (2011). Manajemen Proyek, Perencanaan, Penjadwalan, \& Pengendalian Proyek. Yogyakarta: Andi Yogyakarta.

Junaidi. (2010). Tabel $r$ (Koefisien Korelasi Sedehana) $d f=1-200 . \quad$ [Online] Tersedia di http://junaidichaniago.wordpress.com. [Diakses pada: 10 Maret 2016].

Manuasri, L. K. A. (2011). Manajemen Risiko pada Proyek Konstruksi di Pemerintah Kabupaten Jembrana. Denpasar: Universitas Udayana.

Nanang, A. (2005). Manajemen Risiko. [Online] Tersedia di: http://slideplayer.info/slide/1954286/. [Diakses pada : 29 Maret 2016].

Nasution, M. A. (1992). Metode Research. Yogyakarta: Rake Sarasin.

Norken, I. N., Purbawijaya, I. B. N., \& Suputra, I. G. N. O. (2015). Pengantar Analisis Manajemen Risiko Proyek Konstruksi. Denpasar: Udayana University Press.

Nurhayati. (2010). Manajemen Proyek Konstruksi. Cetakan pertama. Yogyakarta: Andi Offset.

Nurlela, \& Suprapto, H. (2012). Identifikasi dan Analisis Manajemen Risiko pada Proyek Pembangunan Infrastruktur Bangunan Gedung Bertingkat. [Online] Tersedia di: http://www.ejournal.gunadarma.ac.id/index.php/dekons/article/view/1141. [Diakses pada : 15 Januari 2016].

Purba, E. A., \& Monica, A. K. B. (2015). Analisa Manajemen Risiko pada Proyek PDAM Semarang. [Online] Tersedia di: http://ejournal-s1.undip.ac.id/index.php/jkts. [Diakses pada : 1 Desember 2016].

Putra, S. M. (2015). Identifikasi Faktor-faktor Risiko Terhadap kinerja Biaya Konstruksi pada Proyek 
Pembangunan Gedung Bertingkat. Jember: Universitas Jember.

Rumimper, R. R. (2015). Analisis Resiko pada Proyek Konstruksi Perumahan di Kabupaten Minahasa Utara. [Online] Tersedia di: http://ejournal.unsrat.ac.id/index.php/jime/article/view/9966/9552. [Diakses pada : 15 Januari 2016].

Setiawan, P. F. (2014). Manajemen Risiko Proyek Vale di PT. Multipanel Intermitra Mandiri. [Online] Tersedia di: http://e-journal.uajy.ac.id/5660/1/Jurnal.pdf. [Diakses pada: 15 Januari 2016].Soeharto, I. 1995, Manajemen Proyek dari Konseptual sampai Operasional, Cetakan pertama. Jakarta: Gelora Aksara Pratama.

Sugiyono. (2004). Metode Penelitian Kuantitatif, Kualitatif dan R\&D. Bandung: Alfabeta.

Suherman, S. A. (2010). Tips Jitu Menang Tender Menjadi Pemenang Sebelum Tender Dimulai. Cetakan 1. Yogyakarta: Media Pressindo.

Suputra, I. G. N. O. (2005). Identifikasi Risiko pada Pelaksanaan Pembangunan Denpasar Sewerage Development Project (DSDP) di Denpasar. Denpasar: Universitas Udayana.

Thompson, P. A., \& Perry, J. G. (1991). Engineering Construction Risk. London: Thomas Telford Ltd.

\section{Copyrights}

Copyright for this article is retained by the author(s), with first publication rights granted to the journal.

This is an open-access article distributed under the terms and conditions of the Creative Commons Attribution license (http://creativecommons.org/licenses/by/4.0/). 